\title{
The Tradeoff between Natriuresis and Cardiac and Renal Fibrosis
}

\author{
Larry Dial, Joe Xie and Joseph I Shapiro*
}

The Joan C Edwards College of Medicine of Marshall University, Huntington, WV, USA

\begin{abstract}
Cardiotonic steroids play a key role in sodium excretion in response to volume expansion. Their effect is mediated through their binding to the $\mathrm{Na} / \mathrm{K}$-ATPase, a membrane ion transporter which has recently been found to serve as scaffolding and signaling protein. These scaffolding and signaling functions not only stimulate natriuresis through the endocytosis of key ion transporters, namely the sodium proton antiporter isoform 3 (NHE3) and itself, but also produces pro-fibrotic effects. The focus of this editorial is to the tradeoff this creates between natriuresis in the short term and progression of cardiac and renal fibrosis in the long term.
\end{abstract}

\section{Historical Perspective}

In 1961, de Wardener et al. introduced a novel concept in renal hemodynamics when he discovered that kidneys were able to increase sodium excretion after saline infusion despite controlling glomerular filtration rate, also considered "factor one" and aldosterone, which was considered "factor two" [1]. Thus, it was proposed that a "Third Factor" existed and that this material was natriuretic in a manner which did not involve GFR or mineralocorticoids. This "Third Factor" was studied by a number of investigators including Schrier et al. [2,3], Kramer and Gonick [4], Bricker et al. [5], and Gruber et al. [6]; the collective wisdom was that this "third factor" was an endogenous digitalis-like substance or Cardiotonic Steroid (CTS) [2-6]. We now know that endogenous CTS include cardenolides such as ouabain and bufadienolides such as marinobufagenin [7-10]. Ouabain and marinobufagenin have been detected in human plasma and urine $[7,9,11]$.

In addition to their role in renal physiology, scientists were also interested in the cardiac effects of these CTS. In 1963, Repke was suggested that the $\mathrm{Na} / \mathrm{K}$-ATPase was the receptor for digitalis [12]. Since then, extensive studies from many laboratories revealed that CTS were specific ligands for the $\mathrm{Na} / \mathrm{K}$-ATPase, and in fact, produced their physiological effects through binding to the plasmalemmal $\mathrm{Na} / \mathrm{K}-\mathrm{ATP}$ ase [13]. For many years, it was assumed that this binding produced inhibition of the enzymatic and ion pumping aspect of the $\mathrm{Na} / \mathrm{K}-\mathrm{ATPase}$, but more recent data which we will discuss below has cast some doubt upon this assumption.

The Na/K-ATPase is a member of the P-type ATPase family and is responsible for the active transport of $\mathrm{Na}$ and $\mathrm{K}$ ions across animal cell membranes with energy supplied via the hydrolysis of ATP [14]. The structure and ion pumping function have been extensively studied. The currently accepted (Post-Albers) model proposes that there is are noncovalently linked alpha and beta subunits, of which multiple isoforms in various combinations exist [15] which undergo conformational changes and reversible phosphorylation depending on whether sodium is being pumped out of the cell or potassium is being pumped in. Four alpha isoforms and three beta isoforms have been identified with their expression having tissue specificities, as well as differences in sensitivity to CTS. The alpha-1 isoform which demonstrates considerable species differences in sensitivity to CTS also appears to be the main functional receptor for CTS in the kidney [16-20].

Classically, the mechanism of CTS-induced natriuresis was understood as follows: volume expansion or a salt-heavy diet leads to an increase in circulating CTS, which in turn results in the inhibition of the $\mathrm{Na} / \mathrm{K}$-ATPase in the nephron, specifically, its ion pumping ability. Consequently, cytosolic $\mathrm{Na}+$ begins to rise, and eventually this disruption in the $\mathrm{Na}+$ gradient across the cell membrane decreases $\mathrm{Na}$ reabsorption in the Renal Proximal Tubules (RPT) leading to increased sodium excretion [21]. Systemically, increased levels of CTS also inhibit the $\mathrm{Na} / \mathrm{K}$-ATPase in vasculature, thereby altering intracellular $\mathrm{Na}$ gradients in vascular smooth muscle cells. This indirectly leads to the inhibition of the $\mathrm{Na} / \mathrm{Ca}$ exchanger causing intracellular calcium in these smooth muscle cells to rise as well [21-23]. This pathway has been implicated in the pathogenesis of hypertension [21].

More recently, Xie et al. [24] suggested in the late 1990s that the $\mathrm{Na} / \mathrm{K}-\mathrm{ATP}$ ase had an additional signaling function which was related to its function as a scaffolding protein. These workers proposed that CTS also bound to a non-pumping pool of $\mathrm{Na} / \mathrm{K}$-ATPase residing in caveolae [24]. This subset of Na/K-ATPase bound the protein Src, a non-receptor tyrosine kinase, and under basal circumstances kept it in an inactive state. With the conformational change induced by CTS binding, Src was activated and a signal cascade involving the Epithelial Growth Factor Receptor (EGFR) and downstream targets such as Ras/ Raf/MAPK, PI3 kinase/Akt, phospholipase C/PKC, and the generation of ROS was produced [25-32]. Work by our laboratories demonstrated that this signal cascade was directly linked to $\mathrm{Na} / \mathrm{K}$-ATPase and NHE3 endocytosis in renal proximal tubule cells and natriuresis in response to a sodium load [33-37]. Support for this theory was provided by other groups as well. Lingrel et al. first established that ouabain binding to the $\mathrm{Na} / \mathrm{K}$-ATPase is crucial in the natriuretic response of the kidney. His laboratory developed ouabain-sensitive mice by incorporating a mutation in the ouabain receptor domain of the mouse alpha-1 $\mathrm{Na} / \mathrm{K}$-ATPase and noted that saline infusion increased the natriuretic response in ouabain-sensitive in comparison to ouabain-resistant mice [38]. More recently, Nascimento showed that bufalin, another derivative of the bufadienolides required $\mathrm{Na} / \mathrm{K}$-ATPase signaling in order to produce natriuretic effects in isolated rat kidneys [39]. More recently, our group demonstrated that high-salt diets in Dahl salt-

*Corresponding author: Joseph I. Shapiro, Dean, Joan C Edwards College of Medicine, 1600 Medical Center Drive, Suite 3408, Huntington, WV, USA, Tel: 25701-3655; E-mail: shapiroj@marshall.edu

Received November 29, 2012; Accepted December 05, 2012; Published December 13, 2012

Citation: Dial L, Xie J, Shapiro JI (2012) The Tradeoff between Natriuresis and Cardiac and Renal Fibrosis. J Hypertens 1:e108. doi:10.4172/2167-1095.1000e108

Copyright: @ 2012 Dial L, et al. This is an open-access article distributed under the terms of the Creative Commons Attribution License, which permits unrestricted use, distribution, and reproduction in any medium, provided the original author and source are credited. 
resistant rats (R) induced the endocytosis of RPT Na/K-ATPase and NHE3 transporters concurrent with increased Src activity. In contrast, $\mathrm{Na} / \mathrm{K}$-ATPase signaling was markedly attenuated in Dahl salt-sensitive rats $(\mathrm{S})[40]$.

\section{Natriuresis vs. Fibrosis}

Using an experimental renal failure model induced by segmental infarction of one kidney and removal of the contralateral kidney $\left(5 / 6^{\text {th }}\right.$ nephrectomy), we noted that the development of cardiac hypertrophy and fibrosis in both rats and mice appeared to involve an increase in systemic oxidative stress. Interestingly, this oxidant stress appears to depend on increased levels of circulating MBG [41-44]. In other words, the oxidant stress associated with renal failure may be due to the increased signaling of CTS through the $\mathrm{Na} / \mathrm{K}$-ATPase, a concept different from prevailing opinions which implicated inflammation as the central cause of this oxidant stress [43-45].

These physiological and morphological findings in the animal models corresponded to evidence of signaling through the $\mathrm{Na} / \mathrm{K}$-ATPase as we detected activation of both Src and MAPK phosphorylation in the fibrotic cardiac tissue. These results were similarly demonstrated in rats subjected to MBG infusion. However, after adrenalectomy to lower circulating levels of MBG and either active immunization against an MBG-albumin conjugate or passive immunization using a monoclonal developed against MBG or the ovine antibody fragment, Digibind, cardiac fibrosis was significantly reduced in both partial nephrectomy and MBG-infusion experimental groups [42,43,46-48].

Work from other groups also supports this concept. Wansapura et al. [49] subjected genetically altered ouabain-sensitive mice (originally developed by Lingrel) to aortic banding in order to simulate a pressure overload model. After four weeks, the ouabain-sensitive group was noted to have developed substantially greater cardiac hypertrophy and fibrosis compared to ouabain-resistant (wild-type) mice. Furthermore, the administration of Digibind to the ouabain-sensitive mice diminished these cardiac changes [49]. Using cultures of rat cardiac and renal fibroblasts as well as human dermal fibroblasts, we found that CTS were able to directly increase collagen production and proline incorporation [42,50,51]. By inducing a translocation of PKC to the nucleus, MBG appears to cause the subsequent phosphorylation and degradation of Friend leukemia integration-1 (Fli-1), which Watson et al. [52] have demonstrated is a negative regulator of collagen synthesis in dermal fibroblasts [50,52]. We also observed that MBG infusion stimulates the expression and nuclear translocation of snail, a transcription factor involved in epithelial-mesenchymal transition, which is implicated in renal fibrosis [53].

In addition to the above, we also examined the effects of spironolactone, known to be a competitive antagonist of CTS binding to the $\mathrm{Na} / \mathrm{K}$-ATPase, as well as its major metabolite, canrenone on the development and progression of this model of uremic cardiomyopathy. We found that spironolactone significantly attenuated cardiac fibrosis in the renal failure models, and both spironolactone and canrenone reduced collagen production in cardiac fibroblasts [54]. It was further demonstrated that spironolactone blocked MBG-induced $\mathrm{Na} / \mathrm{K}-\mathrm{ATPase}$ signaling both in vivo as well as CTS binding to the plasmalemmal $\mathrm{Na} / \mathrm{K}$-ATPase [54].

\section{Conclusions}

Endogenous circulating CTS are up regulated in the response to volume expansion. The binding of CTS to their receptor, the $\mathrm{Na} / \mathrm{K}$ ATPase, leads to decreased proximal tubular sodium reabsorption and increased natriuresis. Our data suggest that this is likely due to the recently discovered scaffolding and signaling functions of the $\mathrm{Na} / \mathrm{K}$ ATPase. Unfortunately, this same process in fibroblasts is profibrotic, and this leads to a trade-off between sodium homeostasis in the short term and progressive cardiac and renal fibrosis in the long term. We further speculate that this may explain the long term deleterious effects of a high salt diet on cardiovascular health.

\section{References}

1. de Wardener HE, Clarkson EM, Nutbourne DM, Schrier RW, Talner LB, et al. (1971) Evidence for a hormone other than aldosterone which controls urinary sodium excretion. Adv Nephrol Necker Hosp 1: 97-111.

2. Schrier RW, McDonald KM, Marshall RA, Lauler DP (1968) Absence of natriuretic response to acute hypotonic intravascular volume expansion in dogs. Clin Sci 34: 57-72.

3. Schrier RW, Verroust PJ, Jones JJ, Fabian M, Lee J, et al. (1968) Effect of isotonic saline infusion and acute haemorrhage on plasma oxytocin and vasopressin concentrations in dogs. Clin Sci 35: 433-443.

4. Kramer HJ, Gonick HC (1974) Effect of extracellular volume expansion on renal Na-K-ATPase and cell metabolism. Nephron 12: 281-296.

5. Bricker NS, Schmidt RW, Favre H, Fine L, Bourgoignie JJ (1975) On the biology of sodium excretion: The search for a natriuretic hormone. Yale $\mathrm{J}$ Biol Med 48: 293-303.

6. Gruber KA, Whitaker JM, Buckalew VM Jr. (1980) Endogenous digitalis-like substance in plasma of volume-expanded dogs. Nature 287: 743-745.

7. Bagrov AY, Fedorova OV, Dmitrieva RI, Howald WN, Hunter AP, et al. (1998) Characterization of a urinary bufodienolide $\mathrm{Na}+, \mathrm{K}+-\mathrm{ATP}$ ase inhibitor in patients after acute myocardial infarction. Hypertension 31: 1097-1103.

8. Sich B, Kirch U, Tepel M, Zidek W, Schoner W (1996) Pulse pressure correlates in humans with a proscillaridin A immunoreactive compound. Hypertension 27 1073-1078.

9. Hamlyn JM, Blaustein MP, Bova S, DuCharme DW, Harris DW, et al. (1991) Identification and characterization of a ouabain-like compound from human plasma. Proc Natl Acad Sci U S A 88: 6259-6263.

10. Komiyama Y, Dong XH, Nishimura N, Masaki H, Yoshika M, et al. (2005) A novel endogenous digitalis, telocinobufagin, exhibits elevated plasma levels in patients with terminal renal failure. Clin Biochem 38: 36-45.

11. Lichtstein D, Gati I, Samuelov S, Berson D, Rozenman Y, et al. (1993) Identification of digitalis-like compounds in human cataractous lenses. Eur Biochem 216: 261-268

12. Repke K (1963) New Aspects of Cardiac Glycosides. First International Pharmacological Meeting: Pergamon Press, New York USA.

13. Hamlyn JM, Ringel R, Schaeffer J, Levinson PD, Hamilton BP, et al. (1982) A circulating inhibitor of $(\mathrm{Na}++\mathrm{K}+)$ ATPase associated with essential hypertension. Nature 300: 650-652.

14. Skou JC (1957) The influence of some cations on an adenosine triphosphatase from peripheral nerves. Biochim Biophys Acta 23: 394-401.

15. Kaplan JH (2002) Biochemistry of Na,K-ATPase. Annu Rev Biochem 71: 511 535

16. Blanco G, Mercer RW (1998) Isozymes of the Na-K-ATPase: heterogeneity in structure, diversity in function. Am J Physiol 275: F633-F650

17. Sweadner KJ (1989) Isozymes of the Na+/K+-ATPase. Biochim Biophys Acta 988: $185-220$

18. Lingrel JB, Kuntzweiler T (1994) Na+,K(+)-ATPase. J Biol Chem 269: 19659 19662.

19. Dostanic-Larson I, Van Huysse JW, Lorenz JN, Lingrel JB (2005) The highly conserved cardiac glycoside binding site of $\mathrm{Na}, \mathrm{K}-\mathrm{ATP}$ ase plays a role in blood pressure regulation. Proc Natl Acad Sci U S A 102: 15845-15850.

20. Dostanic-Larson I, Lorenz JN, Van Huysse JW, Neumann JC, Moseley AE, et al. (2006) Physiological role of the alpha1- and alpha2-isoforms of the $\mathrm{Na}+-\mathrm{K}+$ ATPase and biological significance of their cardiac glycoside binding site. Am J Physiol Regul Integr Comp Physiol 290: R524-R528. 
Citation: Dial L, Xie J, Shapiro JI (2012) The Tradeoff between Natriuresis and Cardiac and Renal Fibrosis. J Hypertens 1:e108. doi:10.4172/21671095.1000e108

21. Blaustein MP, Hamlyn JM (2010) Signaling mechanisms that link salt retention to hypertension: endogenous ouabain, the $\mathrm{Na}(+)$ pump, the $\mathrm{Na}(+) / \mathrm{Ca}(2+)$ exchanger and TRPC proteins. Biochim Biophys Acta 1802: 1219-1229.

22. Blaustein MP (1993) Physiological effects of endogenous ouabain: contro of intracellular $\mathrm{Ca} 2+$ stores and cell responsiveness. Am J Physiol 264: C1367-C1387

23. Zhang J, Lee MY, Cavalli M, Chen L, Berra-Romani R, et al. (2005) Sodium pump alpha2 subunits control myogenic tone and blood pressure in mice. $J$ Physiol 569: 243-256.

24. Liang M, Tian J, Liu L, Pierre S, Liu J, et al. ( 2007) Identification of a pool of non-pumping Na/K-ATPase. J Biol Chem 282: 10585-10593.

25. Haas M, Askari A, Xie Z (2000) Involvement of Src and epidermal growth factor receptor in the signal-transducing function of $\mathrm{Na}+/ \mathrm{K}+-\mathrm{ATPase}$. J Biol Chem 275: $27832-27837$.

26. Haas M, Wang H, Tian J, Xie Z (2002) Src-mediated inter-receptor cross-talk between the $\mathrm{Na}+/ \mathrm{K}+-\mathrm{ATP}$ ase and the epidermal growth factor receptor relays the signal from ouabain to mitogen-activated protein kinases. J Biol Chem 277 18694-18702.

27. Liu J, Tian J, Haas M, Shapiro JI, Askari A, et al. (2000) Ouabain interaction with cardiac $\mathrm{Na}+/ \mathrm{K}+-\mathrm{ATP}$ ase initiates signal cascades independent of changes in intracellular $\mathrm{Na}+$ and $\mathrm{Ca} 2+$ concentrations. J Biol Chem 275: 27838-27844.

28. Liu L, Mohammadi K, Aynafshar B, Wang H, Li D, et al. (2003) Role of caveolae in signal-transducing function of cardiac $\mathrm{Na}+/ \mathrm{K}+-\mathrm{ATPase}$. Am J Physiol Cell Physiol 284: C1550-C1560

29. Tian J, Cai T, Yuan Z, Wang H, Liu L, et al. (2006) Binding of Src to Na+/K+ATPase forms a functional signaling complex. Mol Biol Cell 17: 317-326.

30. Wang H, Haas M, Liang M, Cai T, Tian J, et al. (2004) Ouabain assembles signaling cascades through the caveolar $\mathrm{Na}+/ \mathrm{K}+-\mathrm{ATPase}$. J Biol Chem 279: 17250-17259.

31. Xie Z, Askari A (2002) $\mathrm{Na}(+) / \mathrm{K}(+)$-ATPase as a signal transducer. Eur $J$ Biochem 269: 2434-2439.

32. Yuan Z, Cai T, Tian J, Ivanov AV, Giovannucci DR, et al. (2005) Na/K-ATPase tethers phospholipase $\mathrm{C}$ and IP3 receptor into a calcium-regulatory complex. Mol Biol Cell 16: 4034-4045.

33. Cai H, Wu L, Qu W, Malhotra D, Xie Z, et al. (2008) Regulation of apical NHE3 trafficking by ouabain-induced activation of the basolateral Na+-K+-ATPase receptor complex. Am J Physiol Cell Physiol 294: C555-C563.

34. Liu J, Kesiry R, Periyasamy SM, Malhotra D, Xie Z, et al. (2004) Ouabain induces endocytosis of plasmalemmal $\mathrm{Na} / \mathrm{K}$-ATPase in LLC-PK1 cells by a clathrin-dependent mechanism. Kidney Int 66: 227-241.

35. Liu J, Liang M, Liu L, Malhotra D, Xie Z, et al. (2005) Ouabain-induced endocytosis of the plasmalemmal Na/K-ATPase in LLC-PK1 cells requires caveolin-1. Kidney Int 67: 1844-1854.

36. Oweis S, Wu L, Kiela PR, Zhao H, Malhotra D, et al. (2006) Cardiac glycoside downregulates NHE3 activity and expression in LLC-PK1 cells. Am J Physiol Renal Physiol 290: F997-F1008.

37. Periyasamy SM, Liu J, Tanta F, Kabak B, Wakefield B, et al. (2005) Salt loading induces redistribution of the plasmalemmal Na/K-ATPase in proximal tubule cells. Kidney Int 67: 1868-1877.

38. Loreaux EL, Kaul B, Lorenz JN, Lingrel JB (2008) Ouabain-Sensitive alpha1 $\mathrm{Na}, \mathrm{K}-\mathrm{ATPase}$ enhances natriuretic response to saline load. J Am Soc Nephro 19: 1947-1954.

39. Arnaud-Batista FJ, Costa GT, Oliveira IM, Costa PP, Santos CF, et al. (2012) Natriuretic effect of bufalin in isolated rat kidneys involves activation of the $\mathrm{Na}+$ K+-ATPase-Src kinase pathway. Am J Physiol Renal Physiol 302: F959-F966.

40. Liu J, Yan Y, Liu L, Xie Z, Malhotra D, et al. (2011) Impairment of Na/KATPase signaling in renal proximal tubule contributes to Dahl salt-sensitive hypertension. J Biol Chem 286: 22806-22813.

41. Hostetter TH, Olson JL, Rennke HG, Venkatachalam MA, Brenner BM (1981) Hyperfiltration in remnant nephrons: a potentially adverse response to renal ablation. Am J Physiol 241: F85-F93.

42. Elkareh J, Kennedy DJ, Yashaswi B, Vetteth S, Shidyak A, et al. (2007) Marinobufagenin stimulates fibroblast collagen production and causes fibrosis in experimental uremic cardiomyopathy. Hypertension 49: 215-224.
43. Kennedy DJ, Vetteth S, Periyasamy SM, Kanj M, Fedorova L, et al. (2006) Central role for the cardiotonic steroid marinobufagenin in the pathogenesis of experimental uremic cardiomyopathy. Hypertension 47: 488-495.

44. Kennedy DJ, Elkareh J, Shidyak A, Shapiro AP, Smaili S, et al. (2008) Partia nephrectomy as a model for uremic cardiomyopathy in the mouse. Am Physiol Renal Physiol 294: F450-F454.

45. Himmelfarb J, McMonagle E (2001) Manifestations of oxidant stress in uremia Blood Purif 19: 200-205

46. Himmelfarb J, Stenvinkel P, Ikizler TA, Hakim RM (2002) The elephant in uremia: oxidant stress as a unifying concept of cardiovascular disease in uremia. Kidney Int 62: 1524-1538.

47. Himmelfarb J, McMonagle E, Freedman S, Klenzak J, McMenamin E, et al. (2004) Oxidative stress is increased in critically ill patients with acute renal failure. J Am Soc Nephrol 15: 2449-2456.

48. Haller ST, Kennedy DJ, Shidyak A, Budny GV, Malhotra D, et al. (2012) Monoclonal antibody against marinobufagenin reverses cardiac fibrosis in rats with chronic renal failure. Am J Hypertens 25: 690-696.

49. Wansapura AN, Lasko VM, Lingrel JB, Lorenz JN (2011) Mice expressing ouabain-sensitive a1-Na,K-ATPase have increased susceptibility to pressure overload-induced cardiac hypertrophy. Am J Physiol Heart Circ Physiol 300 H347-H355.

50. Elkareh J, Periyasamy SM, Shidyak A, Vetteth S, Schroeder J, et al. (2009) Marinobufagenin induces increases in procollagen expression in a process involving protein kinase $\mathrm{C}$ and $\mathrm{Fli}-1$ : implications for uremic cardiomyopathy. Am J Physiol Renal Physiol 296: F1219-F1226.

51. El-Okdi N, Smaili S, Raju V, Shidyak A, Gupta S, et al. (2008) Effects of cardiotonic steroids on dermal collagen synthesis and wound healing. J Appl Physiol 105: 30-36

52. Czuwara-Ladykowska J, Shirasaki F, Jackers P, Watson DK, Trojanowska M (2001) Fli-1 inhibits collagen type I production in dermal fibroblasts via an Sp1dependent pathway. J Biol Chem 276: 20839-20848.

53. Fedorova LV, Raju V, El-Okdi N, Shidyak A, Kennedy DJ, et al. (2009) The cardiotonic steroid hormone marinobufagenin induces renal fibrosis: implication of epithelial-to-mesenchymal transition. Am J Physiol Renal Physiol 296: F922F934.

54. Tian J, Shidyak A, Periyasamy SM, Haller S, Taleb M, et al. (2009) Spironolactone attenuates experimental uremic cardiomyopathy by antagonizing marinobufagenin. Hypertension 54: 1313-1320. 